\title{
ВПРОВАДЖЕННЯ ЛОГІСТИЧНИХ ПІДХОДІВ ДО АНАЛІЗУ ПЕРСПЕКТИВ РОЗВИТКУ МІЖНАРОДНИХ ПАСАЖИРСЬКИХ ЗАЛІЗНИЧНИХ ПЕРЕВЕЗЕНЬ
}

\author{
Альошинський $\boldsymbol{C}$. С., $\partial$. т. н. \\ Примаченко Г. О., к. т. н.
}

Украӥна, м. Харків, Украӥнський державний університет залізничного транспорту

\section{DOI: https://doi.org/10.31435/rsglobal_ejits/30112018/6221}

\author{
ARTICLE INFO \\ Received 03 August 2018 \\ Accepted 22 November 2018

\section{KEYWORDS} \\ international passenger \\ transportation, \\ diversification, \\ project variants, \\ SWOT analysis, \\ logistics research.
}

Published 30 November 2018

\begin{abstract}
One of the most promising directions of solving the satisfying constantly growing problem of Ukrainians residents tourist, business and migration activity is the diversification of the rail transport activity in the international passenger transportation market. In the conducted studies, the analysis of possible variants of passenger transportation logistics from Eastern Ukraine (in particular from Kharkiv) to Krakow was made. For comparison, seven possible variants of transportation and a new project solution (direct passenger train Kharkiv - Kiev - Lviv - Mostiska II - Krakow with the perspective of continuation of the route to Prague or Vienna) is selected. Based on the SWOT analysis, as well as marketing and logistics research on project variants, it has been proved that the proposed direct rail rout between Kharkiv and Krakow can compete on an equal footing with existing variants of transport.
\end{abstract}

Citation: Альошинський Є. С., Примаченко Г. О. (2018) Vprovadzhennia Lohistychnykh Pidkhodiv do Analizu Perspektyv Rozvytku Mizhnarodnykh Pasazhyrskykh Zaliznychnykh Perevezen. European Journal of Intelligent Transportation Systems. 1(1). doi: 10.31435/rsglobal_ejits/30112018/6221

Copyright: (C) 2018 Альошинський С. С., Примаченко Г. О. This is an open-access article distributed under the terms of the Creative Commons Attribution License (CC BY). The use, distribution or reproduction in other forums is permitted, provided the original author(s) or licensor are credited and that the original publication in this journal is cited, in accordance with accepted academic practice. No use, distribution or reproduction is permitted which does not comply with these terms.

Вступ. Останнім часом серед українців та мешканців Свропи значно збільшився попит на міжнародні пасажирські та туристичні перевезення. Але ж в даний час пасажир найчастіше сам виступає логістом своїх поїздок, не маючи при цьому повних даних щодо надійності та безпеки транспортних мереж, рухомого складу різних видів транспорту, розкладів руху і маршрутів слідування.

Впровадження логістичних підходів до розвитку пасажирської транспортної системи України дозволить пасажиру самостійно приймати рішення про варіант здійснення поїздки в залежності від найбільш важливих для нього факторів i характеристик транспортного обслуговування. ПАТ «Укрзалізниця» та Польські залізниці (РКР) мають унікальну можливість допомогти пасажирам у наданні інформаційних й логістичних послуг, а також у виборі найбільш сприятливих варіантів перевезень. Для цього необхідно організовувати пасажирський рух між найбільшими містами Європи та надати пасажирам змогу зручно і швидко перетинати кордон. Тому одним з найбільш перспективних напрямів вирішення наведеної проблеми $є$ диверсифікація діяльності залізничного транспорту на ринку послуг туристичних та міжнародних пасажирських перевезень. Розширення мережі міжнародних залізничних маршрутів надасть змогу 
привернути пасажирів з інших видів транспорту, а також збільшити відсоток туристів, які планують відвідати популярні куточки як України, так й інших країн $Є С[1,2]$.

Результати досліджень. Однак, слід зауважити, що на сьогодні залізничний транспорт на цьому сегменті ринку не дуже популярний, що пояснюється рядом причин:

1) низька варіативність вибору маршрутів перевезень (найбільш затребуваний на сьогодні напрямок перевезень між Україною та Польщею (не враховуючи поїзд Інтерсіті+ 3 Київа до Перемишля) обслуговує лише 1 поїзд, що ходить маршрутом Київ - Варшава);

2) неконкурентна вартість перевезень залізничним транспортом (вартість квитка в купейному вагоні сягає 2600 грн.);

3) низький рівень сервісу при бронюванні квитка міжнародного сполучення (необхідність сплати лише готівкою, відсутність можливості дистанційного придбання квитків, відсутність інформації в базі даних при покупці квитка (при втраті квитка необхідно покупати новий квиток));

4) низький рівень комфорту при поїздці сидячи;

5) відсутність вагону-ресторану тощо.

У зв’язку із цим більшість пасажирів віддає перевагу іншим видам перевезень. Зокрема повітряному або автомобільному транспорту.

Таким чином, хоча й останнім часом в Україні туристичні та ділові подорожі в напрямку країн Свросоюзу набувають все більшої популярності, але ж система міжнародних пасажирських залізничних перевезень України як й суміжних країн розвивається нерівномірно і в ряді випадків стихійно під впливом потреб клієнтів, технічних і технологічних можливостей, а також ряду зовнішніх чинників: політичних, економічних, соціальних та екологічних.

В зв'язку із цим постає задача систематизації процесу вибору нових конкурентоспроможних маршрутів, в тому числі зоснованих на логістичних принципах.

Як зазначалось, в Україні останнім часом все більшої популярності набувають туристичні та ділові подорожі в напрямку країн Свросоюзу (при чому найчастіше як кінцевий пункт призначення розглядається саме Польща). Найбільшою популярністю у мешканців України користується регіон Панства Малопольського (міста Краків, Катовіце, Закопане, пригірські Татри тощо), а також Вроцлав. Але на сьогодні ці регіони виглядають для українців доступними здебільше 3 використанням повітряного та автомобільного/автобусного сполучення.

Для вирішення цієї проблеми на 1-му етапі дослідження проведено аналіз можливих варіантів логістики перевезень пасажирів найбільш вірогідними із можливих варіантів надання транспортних послуг зі Східної України (зокрема з Харкова через Київ та Львів) до Кракова $[3,5,6]$.

Для порівняння обрано вісім з безлічі можливих варіантів:

1. Залізнично-повітряний (пасажирський поїзд Харків - Полтава - Київ 3 пересадкою на літак до Кракова)

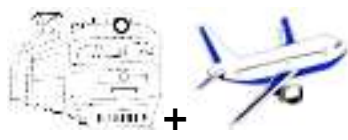

2. Повітряний (літак Харків - Краків)

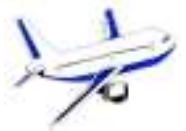
Краків)

3. Повітряно-залізничний (літак Харків - Варшава з пересадкою на поїзд Варшава -

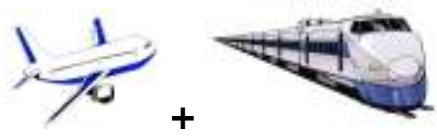


4. Автобусний (прямий автобус Харків - Краків)

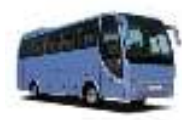

5. Залізнично-автобусний (пасажирський поїзд Харків - Львів з пересадкою на автобус Львів - Краків)

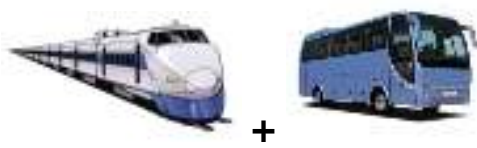

6. Залізничний (пасажирський поїзд Харків - Львів 3 пересадкою на поїзд Інтерсіті+ Львів - Перемишль з подальшою пересадкою на поїзд Інтерсіті+ Перемишль - Краків)

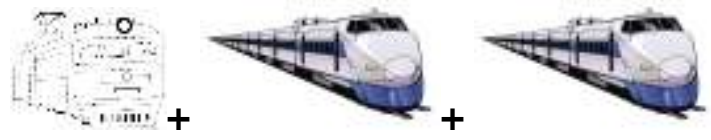

7. Залізничний (пасажирський поїзд Харків - Київ з пересадкою на поїзд Інтерсіті+ Київ - Перемишль 3 подальшою пересадкою на поїзд Інтерсіті+ Перемишль - Краків)

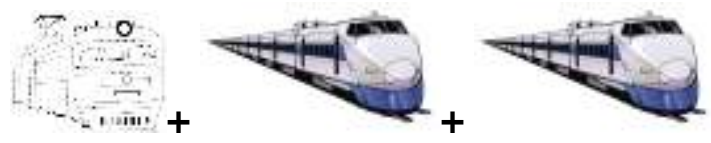

8. Залізничний (прямий пасажирський поїзд Харків - Краків)

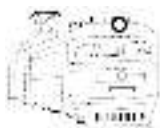

Таким чином, щоб підтримати та в перспективі збільшити пасажирообіг між Україною та Польщею пропонується для порівняння вже існуючі варіанти перевезень (варіанти №1-7) та нове проектне рішення (варіант №8 - пасажирський поїзд Харків Київ - Львів - Мостиска II - Краків з перспективою продовження маршруту до Праги або Відня).

Митні процедури в проектному варіанті проводяться безпосередньо в русі поїзда, тому простої на кордоні відсутні. Зміну колісних пар з підняттям кузовів вагонів на кордоні можна проводити на станції Мостиска II (в далекій перспективі можливо впровадження розсувних колісних пар). Проїзд пропонується організовувати 2 рази на тиждень в купейних вагонах міжнародного сполучення (з 3-місними купе) загальною місткістю до 33 пасажирів. Прогнозний середній час в дорозі для проектного варіанту приблизно 18 год., проектна середня вартість - на рівні 75€ (орієнтовно від 2300 грн.).

На наступному етапі дослідження виконано SWOT-аналіз запропонованих рішень, фрагменти результатів якого наведено таблиці 1. 
Таблиця 1 - SWOT-аналіз проектних варіантів

\begin{tabular}{|c|c|c|}
\hline $\begin{array}{c}\text { Варіанти } \\
\text { маршрутів }\end{array}$ & Переваги/можливості маршруту & Недоліки/ризики маршруту \\
\hline $\begin{array}{l}\text { 1. Залізнично- } \\
\text { повітряний }\end{array}$ & $\begin{array}{l}\text { - щоденний доступ; } \\
\text { - відносно швидкий митний контроль; } \\
\text { - час в дорозі дещо менший ніж в } \\
\text { деяких варіантах }\end{array}$ & $\begin{array}{l}\text { - висока вартість; } \\
\text { - наявність пересадок; } \\
\text { - прибуття поїзда до Києва в } \\
\text { незручний час (вночі); } \\
\text { - необхідність переміщення на } \\
\text { таксі між вокзалом та аеропортом; } \\
\text { - необхідно мати додатковий час } \\
\text { на реєстрацію в аеропорту; } \\
\text { - додаткові витрати часу та } \\
\text { грошей на трансфери в/з аеропорту; } \\
\text { - авіарейс-непрямий (з пересадкою); } \\
\text { - залежність від погодних умов }\end{array}$ \\
\hline $2,3,4,5,6,7$ & …....... & 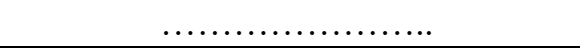 \\
\hline 8. Залізничний & $\begin{array}{l}\text { - час в дорозі менший ніж в інших } \\
\text { варіантах наземних перевезень; } \\
\text { - відсутність пересадок; } \\
\text { - найвищий рівень комфорту проїзду; } \\
\text { - простота проходження митних процедур; } \\
\text { - перспектива продовження рейсу до } \\
\text { Праги або Відня; } \\
\text { - не залежить від зовнішніх факторів }\end{array}$ & $\begin{array}{l}\text { - вартість вище ніж в інших } \\
\text { варіантах наземних перевезень; } \\
\text { - низька доступність (2 рейси/тижд.); } \\
\text { - необхідність придбання нових } \\
\text { вагонів; } \\
\text { - проходження процедури зміни } \\
\text { ширини колії (зміна візків) }\end{array}$ \\
\hline
\end{tabular}

На підставі SWOT-аналізу всіх варіантів виконано узагальнюючий порівняльний аналіз проектний рішень (табл. 2).

Таблиця 2 - Порівняльний аналіз запропонованих варіантів

\begin{tabular}{|c|c|c|c|c|c|c|c|}
\hline $\begin{array}{c}\text { Проектний } \\
\text { варіант }\end{array}$ & Наявність & $\begin{array}{c}\text { Частота } \\
\text { відправлень }\end{array}$ & $\begin{array}{c}\text { Час в } \\
\text { дорозі, год. }\end{array}$ & \begin{tabular}{|c|} 
Орієнтовна \\
вартість \\
поїздки, \\
грн.
\end{tabular} & \begin{tabular}{|c} 
Зручність/ \\
комфорт
\end{tabular} & $\begin{array}{c}\text { Наявність } \\
\text { організаційних } \\
\text { перешкод }\end{array}$ & $\begin{array}{c}\text { Необхідність } \\
\text { капітальних } \\
\text { вкладань }\end{array}$ \\
\hline 1 & 2 & 3 & 4 & 5 & 6 & 7 & 8 \\
\hline $\begin{array}{l}1 \text { Залізнично- } \\
\text { повітряний }\end{array}$ & існує & щоденно & 18,0 & 6340 & - & - & - \\
\hline 2. Повітряний & існує & $\begin{array}{l}1 \text { раз/ тиждень } \\
\text { (перспектива) }\end{array}$ & 7,0 & 5035 & + & - & - \\
\hline $\begin{array}{l}\text { 3. Повітряно- } \\
\text { залізничний }\end{array}$ & існує & 1 раз/ тиждень & 9,0 & 4344 & + & - & - \\
\hline 4. Автобусний & існує & щоденно & 25,0 & 1325 & - & + & - \\
\hline $\begin{array}{l}\text { 5. Залізнично- } \\
\text { автобусний }\end{array}$ & існує & щоденно & 24,5 & 1223 & $+/-$ & + & - \\
\hline 6. Залізничний & $\begin{array}{c}\text { частково } \\
\text { існує }\end{array}$ & щоденно & 24,5 & 1165 & + & - & - \\
\hline 7. Залізничний & існує & щоденно & 23,0 & 1230 & $+/-$ & - & - \\
\hline 8. Залізничний & новий & \begin{tabular}{|c|}
2 рази на \\
тиждень \\
(пропозиція) \\
\end{tabular} & $\begin{array}{c}\text { орієнтовно } \\
18,0\end{array}$ & 2300 & + & - & + \\
\hline
\end{tabular}

Після цього проведено маркетингове та логістичне дослідження проектних варіантів маршрутів між Харковом та Краковом. Виявлено 15 основних факторів, які 
враховували би потенційні пасажири при плануванні подорожі за будь-яким із запропонованих варіантів маршруту (вартість перевезення, доступність, час в дорозі, кількість пересадок в маршруті, комфортність, регулярність перевезень та інші) та їх вагомість. Виконано математичну постановку задачі дослідження, що отримала вигляд цільової функції (1), спрямованої на максимізацію критерію привабливості маршруту.

$$
\begin{aligned}
& K j=\sum_{1}^{15} \hat{O}_{{ }_{3 j}}=f(C j, D j, T j, G j, M j, Z j, B j, O j, Q j, E j, S j, A j, N j, L j, H j) \rightarrow M A X \\
& \left\{\begin{array}{l}
0<K j \leq 1, \\
C j=[0: 1], D j=[0: 1], T j=[0: 1], G j=[0: 1], M j=[0: 1], \\
Z j=[0: 1], B j=[0: 1], O j=[0: 1], Q j=[0: 1], E j=[0: 1], \\
S j=[0: 1], A j=[0: 1], N j=[0: 1], L j=[0: 1], H j=[0: 1], \\
C j+D j+T j+G j+M j+Z j+B j+O j+Q j+E j+S j+A j+N j+L j+H j=1,0
\end{array}\right.
\end{aligned}
$$

де $K j$ - показник привабливості ј-го варіанту перевезення;

$\Phi i j$ - сумарне значення i-х факторів для ј-го варіанту перевезення.

Перелік усіх обраних для аналізу факторів та їх частка вагомості/значущості $\mathrm{W}_{\mathrm{Fi}}$ (згідно досліджень за методом експертних оцінок) наведено в таблиці 3.

3 використанням бального методу [4] виконано рейтингування всіх 8 можливих варіантів маршруту перевезення пасажирів в напрямку Харків-Краків. Це надало можливість відсіяти менш привабливі для потенційних користувачів транспортною послугою варіанти маршрутів (зокрема відсіяно як менш конкурентоспроможні варіанти №№ 1, 3, 4, 5).

Таблиця 3 - Перелік основних факторів для вибору найбільш привабливого

\begin{tabular}{|c|c|c|c|}
\hline № & Фактори & $\begin{array}{l}\text { Позна- } \\
\text { чення }\end{array}$ & $\begin{array}{c}\text { Ваго- } \\
\text { мість } \\
\mathrm{W}_{\mathrm{Fi}}\end{array}$ \\
\hline 1 & Вартість перевезення, грн & $C j$ & 0,21 \\
\hline 2 & Доступність для більшості мешканців України (за 100-бальною шкалою) & $D j$ & 0,03 \\
\hline 3 & Час в дорозі, год. & $T j$ & 0,32 \\
\hline 4 & Своєчасність/ дотримання графіку (за 100-бальною шкалою) & $G j$ & 0,05 \\
\hline 5 & Кількість пересадок, перевірок на кордоні, реєстрацій & $M j$ & 0,08 \\
\hline 6 & Зручність/комфорт (за 100-бальною шкалою) & $Z j$ & 0,11 \\
\hline 7 & Збережність багажу (за 100-бальною шкалою) & $B j$ & 0,01 \\
\hline 8 & Наявність організаційних перешкод та капіталовкладень (шт) & $O j$ & 0,02 \\
\hline 9 & Можливість довготривалості проекту (за 100-бальною шкалою) & $Q j$ & 0,00 \\
\hline 10 & Можливість харчування в дорозі (за 100-бальною шкалою) & $E j$ & 0,02 \\
\hline 11 & Розважально-інформаційний супровід в дорозі (за 100-бальною шкалою) & $S j$ & 0,01 \\
\hline 12 & Імідж перевізника (за 100-бальною шкалою) & $A j$ & 0,01 \\
\hline 13 & Надійність перевезення (за 100-бальною шкалою) & $\mathrm{Nj}$ & 0,03 \\
\hline 14 & Регулярність перевезення (за 100-бальною шкалою) & $L j$ & 0,09 \\
\hline 15 & Додаткові послуги (за 100-бальною шкалою) & $\mathrm{Hj}$ & 0,01 \\
\hline \multicolumn{3}{|c|}{ ВСЬОГО } & 1,00 \\
\hline
\end{tabular}
маршруту

Далі побудовано імітаційну модель, що базується на принципах методу аналізу iєрархії (MAI) [4]. Проведено моделювання процесу оцінки вагомості 4 кращих з 8 потенційних варіантів маршруту перевезення (варіанти №№ 2, 6, 7, 8).

Виявлено, що найбільш привабливим варіантом маршруту перевезення пасажирів в напрямку Харків - Краків став варіант №2, який передбачає перевезення з використанням прямого повітряного сполучення. 2-3 місця поділили варіанти №6 та №8. 


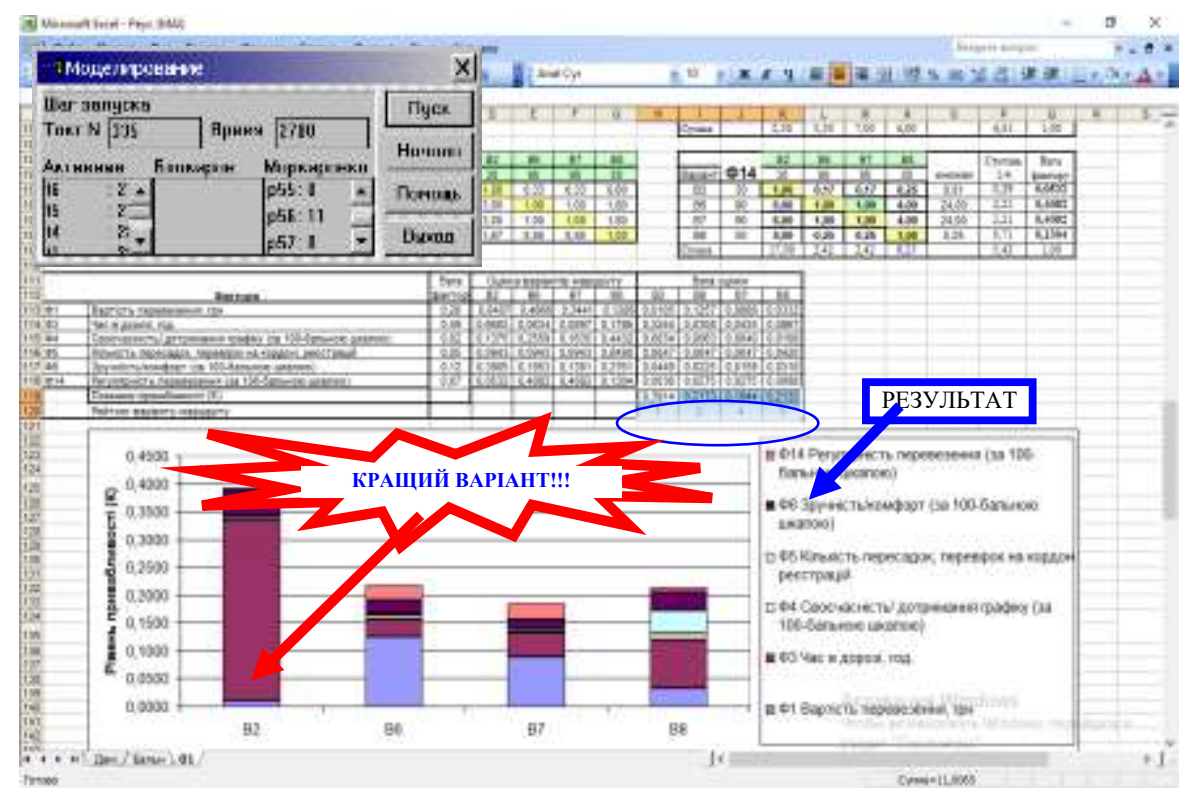

Рис. 1. Вікно програмного інтерфейсу імітаційної моделі оиінки вагомості варіантів марируту перевезення

Висновки. Запропонований в проекті новий варіант перевезень (варіант №8), що передбачає пряме залізничне сполучення може на рівних конкурувати 3 варіантами перевезень у вже впровадженому в 2017 році маршруті Інтерсіті+ (варіанти №№ 6, 7). Проектний варіант (№8) матиме більш високі показники по терміну та зручності перевезень, але поступається по вартості та регулярності сполучень.

Розрахунки економічної привабливості запропонованого проекту маршруту перевезень 3 використанням пасажирського поїзду, що складається 310 купейних спальних вагонів моделі 61-7034 (виробництва Крюківського вагоно-будівельного заводу [7]) довели, що при сумарних капітальних вкладеннях 215 млн. грн. (на придбання нових вагонів), термін окупності проекту складатиме 9 років. При цьому, економічний ефект 3 наростаючим підсумком на 10-й рік експлуатації дорівнюватиме майже 5,5 млн. євро.

Таким чином, розширення мережі міжнародних залізничних маршрутів не лише надасть змогу привернути пасажирів з інших видів транспорту, а й дозволить залучити додаткові інвестиції для розвитку пасажирських залізничних перевезень та економіки держави в цілому.

\section{ЛIТЕРАТУРА}

1. Альошинський Є. С., Примаченко Г. О. Дослідження перспектив розвитку логістики пасажирських залізничних перевезень в країнах Східної Свропи Science and Education a New Dimension. Natural and Technical Sciences. - Budapesht, 2017. - V(15), Issue 140. - C. 52-56.

2. Prymachenko, G. Development of intermodal transport and logistics schemes for passenger transportation by railway transport within Ukraine-Europe direction // V International scientific and technical conference «Engineering. Techologies. Education. Security», 2017. Volume III. Management. Safety and ecology education. Public science, P. 258-260.

3. Мировой атлас данных. Электронный ресурс. Режим доступа: http://knoema.ru/atlas

4. Альошинський Є. С., Лючков Д. С., Челмакіна О. С. Варіантні завдання 3 методичними вказівками 3 дисципліни „Управління ланцюгом постачання” для студентів спеціальності ОПУТ всіх форм навчання. - Харків: УкрДАЗТ, 2013. - 38 с.

5. Офіційний сайт Центра транспортних стратегій: https:/cfts.org.ua/

6. LOT. Польские авиалинии [Електронний ресурс]. Режим доступу: https://www.lot.com/ua/ru/

7. Вагон пасажирський для міжнародного сполучення габариту «RIC» мод. 61-7034 [Електронний peсурс]. Режим доступу: http://www.kvsz.com/index.php/ ua/produktsiya/pasazhirskevagonobuduvannya/pasazhirski-vagoni-seriji-788. 